\title{
CHARTER RIGHTS AND REGULATION BY FINANCIAL INCENTIVES
}

\author{
EUGENE E. DAIS
}

This article challenges the conventional view that the Charter is not applicable to the protection of individuals from regulation by financial incentives. The Charter applies whenever individuals are coerced by govermment. This coercion can be direct and overt, as with punishment, but it can also be indirect and covert as in the case of regulation by licensing, the awarding of contracts and tax incentives. Regulation by financial incentives gives rise to the possibility of subtle coercion in the forms of clever dealing, unconscionable bargains, deceptive expectations and covert punishment. The author argues that the liberty schema of the Charter should apply when regulatory enticement is coercive and not purely facilitative.

\section{TABLE OF CONTENTS}

\section{A SCHEMA OF GOVERNMENTAL POWER . . . . . . . . 594 \\ II. PRACTICAL PROBLEMS OF

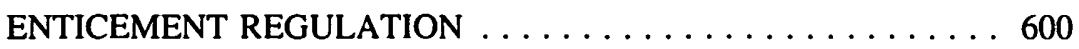

Does the Canadian Charter of Rights and Freedoms protect individuals' against regulation by financial incentives? The conventional view is that primarily for two reasons Charter rights do not apply to such regulation. First, individuals offered financial benefits are not forced to accept them. Charter rights apply only to coercive deterrence, that is, to the compulsion which blatantly deprives or threatens to deprive individuals of that which is their own, their rights to life, liberty and property. They are not designed to protect individuals from themselves. Anyone who accepts benefits from another must be prepared to accept the bad with the good and cannot justly complain if the benefits are conditioned or cease as long as they are free to reject them in the first instance.

Secondly, so the conventional argument goes, government has every right, by its legislative power to tax and spend the money of others, to create or not create benefits as it sees fit. It alone decides what policies best serves the public; and among the various ways of implementing its policies, it may choose to entice compliance by promising benefits rather than compelling it by threatening harms. Individuals have no general right to such benefits for that would mean they could judicially compel government to give them cash subsidies, risky loans and tax exemptions. These concrete rights are rights individuals can have only if they have a completed contract with government the legislature decides not to abrogate, or if the benefits are expressly guaranteed in the

Professor, Faculty of Law, The University of Calgary.

Canadian Charter of Rights and Freedoms, Part I of the Constitution Act, 1982, being Schedule B of the Canada Act 1982 (U.K.), 1982, c. II [hereinafter Charter]. Individual rights in the Charter are the classic rights against government found in ss. 2-15. Excluded from consideration are group and interpretive rights in ss. 16-29 and s. 31. It is assumed that the Charter does not protect one level of government against another level in their capacities as government. Whether units of government may avail themselves of Charter protection when acting as private 'persons' in the strictly fictional sense is also not considered. 
Constitution of Canada. ${ }^{2}$ The power to spend is the greater power and it logically includes the lesser powers arbitrarily to condition the benefits of governmental subsidizing, contracting and licensing, to refuse benefits in whole or in part and to withdraw them. Such benefits, in other words, are merely privileges subject to the arbitrary will of government. ${ }^{3}$

Consequently, it follows according to the conventional view that individuals may be arbitrarily denied permission to practice their lawful vocations, that is, denied for reasons other than such relevant ones as incompetence or dishonesty. When employed by government they may also as a condition of their employment be prohibited from exercising fundamental rights and freedoms. Individuals may, moreover, be enticed to rely financially on the continuance of governmental benefits which can then without concern be terminated unilaterally. ${ }^{4}$ And finally individuals receiving governmental benefits can be denied those benefits by covert punishment as long as such punishment punishes indirectly conduct which government has the power to punish directly.

This conventional theory, however, as its four ramifications suggest, only partially accounts for Charter rights, especially the rights of individuals under s. 2, s. 7 and s. 15, and more importantly, for the underlying principle by which the applicability of Charter rights should be measured. By distinguishing between compulsory obligation, which would be subject to Charter restrictions, and contractual obligation, which would not, it ignores the subtle coercion which regulation by financial incentives may impose. ${ }^{5}$ We may more

2. Constitution Act, 1867 (U.K.), 30 \& 31 Vict., c. 3 [hereinafter Constitution Act, 1867]. For example, the education benefits in s. 93, Constitution Act, 1867, and the language and educational rights in ss. 16-23, Charter.

3. P.W. Hogg, Constitutional Law of Canada, 2d ed. (Toronto: Carswell, 1985) at 126: "There is a distinction, in my view, between compulsory regulation, which can obviously be accomplished only by legislation enacted within the limits of legislative power, and spending or lending or contracting, which either imposes no obligations on the recipient (as in the case of family allowances) or obligations which are voluntarily assumed by the recipient (as in the case of a conditional grant, a loan or a commercial contract). There is no compelling reason to confine spending or lending or contracting within the limits of the legislative power, because in those functions the government is not purporting to exercise any peculiarly governmental authority over its subjects." The significantly different schema of governmental power implicit in this conventional view is revealed by characterizing individuals as 'subjects' instead of as 'persons' or the equivalent which is the Charter's characterization. See infra note 10.

4. It is also true that the Federal government, having the greater taxation power, coencively entices with financial incentives provincial governments to exercise their powers for implementing provincial programs. It would not appear, however, that the provincial governments would have access to Charter protection whose point is to protect individuals from both Federal and provincial governments. Provinces, it would appear have all the protection they deserve under the provisions of the Constitution Act, 1867, especially s. 92.

5. P.W. Hogg, supra note 3, at $126 \mathrm{fn}$. 48: "I appreciate that where there are discrepancies in bargaining power the recipient may not assume obligations 'voluntarily' in the broadest sense of that term; but there is a legal distinction between the consensual assumption of an obligation and the compulsory imposition of an obligation: sec A.G. B.C. v. Esquimalt \& Nanaimo Ry. Co., [1950] A.C. 87, 110" [hereinafter Esquimalt] ('Legislation and contract are entirely different methods of creating rights and liabilities and it is essential to keep them distinct.'). But it is precisely government's 'peculiar' bargaining power which must always be greater than the bargaining power of individuals, even when organized, that is the problem. See also P.W. Hogg, Constitutional Law of Canada 3rd ed., (Toronto: 
accurately call this subtle coercion 'coercion by enticement' (or inducement). ${ }^{6}$ It would appear more sensible, I argue, to draw the line, not between compulsory obligation and voluntary obligation, but between coercion and facilitation. Put negatively, my thesis is that only when governmental regulation is purely facilitative, that is, free of both blatant and subtle coercion, do Charter rights in principle not apply. Positively, my thesis is that insofar as government has coerced individual choice by enticement, irrespective of the form regulation takes, the fundamental freedoms of $s$. 2, the fundamental justice rights of s. 7 and the equality rights of s. 15 should in principle apply subject, of course, to reasonable limitation by $\mathrm{s} .1$.

The coercive-facilitative distinction I propose as the normative test for rights protection against legislative authority, as may be gathered, presupposes a schema of governmental power significantly different from that which would ground the conventional theory. ${ }^{7}$ For this reason, I should set forth the contrary schema I propose. But this is a complex task and can only be approached here in summary fashion. The success of such a schema may be measured, I suggest, by how well it accounts for resolving practical problems in rights protection against enticement coercion. These practical problems may be roughly identified, as already mentioned, as arising when government regulation by enticement

Carswell, 1992) at 152, fn. 41.

6. The notion of incentive while often used in this regulatory context confuses important distinctions. An incentive inspires one to act in a certain direction as when political leaders appeal to patriotism or party loyalty to influence behaviour contrary to inner urges. Inducement is closer to the meaning of government using its finances to change individual behaviour. It has to do with the opportunities one gains by accepting the conditions laid down by another person (or by the situation). It also suggests successful influence whether achieved by argument or by promise of reward. But since regulation by financing is never by argument and can be with or without conditions, enticement is more exact in describing the opposite of regulation by deterrence or compulsion. Enticement means attracting or drawing one toward a certain end, in this case the end government deems good policy, by exciting hope, reward or desire. It is, in a word, coercion by the carrot, not by the stick, by pulling, not by pushing.

In this connection, confusion over the usage of coercion should also be avoided. It can mean either to compel one by constraint or obligation to yield or to do what another wishes as in a creditor compelling an unwilling debtor to pay, or, in contrast, to impel one toward a certain end by providing a strong motive as in human nature impelling one to seek pleasure instead of virtue. Unlike coercion by compulsion which implies change of intended behaviour, coercion by impulsion suggests no necessary change in inclinations but rather may be reinforcing present ones by making them financially possible or more intensely a commitment. Coercion by compulsion or deterrence harms in the blatam sense by threatening to deprive individuals of what is their own, namely, their life, liberty or property in the broad, personal sense. Coercion by impulsion or enticement harms in the subtle sense of holding out benefits or giving them and then implicitly or explicitly threatening to withdraw them. Blatant coercion categorically commands, contrary to one's wishes, to do or not to do or else. Subtle coercion conditionally proposes, contrary to or convergent with one's wishes, that if this is done or not done, then that will be done or not done. Subtle coercion, I argue, takes the forms of clever dealing, unconscionable bargains, deceptive expectations and covert punishment.

7. The schema of the conventional theory on the spending power of government in Canada is not as explicit as in Australia where s. 96 of its constitution specifically authorizes the federal parliament "to grant financial assistance to any state on such terms and conditions as the Parliament thinks fit." But it is still controversial in Australia whether anything goes when the financial assistance is to individuals. See P.W. Hogg, supra note 3 at 126, fn. 5I. Australia, of course, does not have the equivalent of the Canadian Charter. 
takes the forms of clever, unconscionable, deceptive or covert coercion. Accounting for their resolution must, of course, consider how the Supreme Court of Canada has thus far dealt with them. Such an account is sketched in Part II to show the plausibility of the thesis that enticement coercion cannot in principle escape Charter restrictions.

\section{A SCHEMA OF GOVERNMENTAL POWER}

We start from obvious facts however trite they may seem. Government is instituted by a people, among other things, to coerce individual choice. ${ }^{8}$ Successful government regulates coercively as little as possible, wisely economizing its finite resources of physical, economic and psychological force and influence. Such government is not necessarily inactive government. Depending on the political environment, government may be implicated in a wide range and variety of policy tasks. In brief, in its own interest government should use minimal coercion especially when it pursues a maximum of social goals.

The Charter's universal rights are designed to do more than minimize governmental coercion in pursuit of democratic goals. They expressly limit how far government even when its coercion is minimalized may intrude into the lives of individuals. Such rights intend to rule out certain policy objectives despite majoritarian support. These are cases of governmental action, like the Lord's Day Act, ${ }^{9}$ in which the basic principle underlying Charter rights has been directly attacked. This grounding principle may be defensibly formulated in these terms: government should never treat people in ways which fail to acknowledge them as persons ${ }^{10}$ having priceless dignity and equally inviolable rights."

More exactly, government coerces the will of individuals as it manifests itself in their choices to act or not act. Such acts are intentional or purposive behaviours and as such can be controlled in ways in which animals cannot be controlled. Individuals can be intentionally moved to action by interests or by moral convictions. Or, like animals, they can, alternatively, be mechanically manipulated to act by threats of harms (the stick) or by promises of rewards (the carrot).

The distinction is shown by the old saying that you can lead a horse to water but you can't make it drink. It depends on the horse, of course, whether getting it to water works best by the stick or the carrot. Once there, however, 'punishing' the horse for disobedience to authorized commands to drink makes no sense. Physical violence can be administered only like torture, to break the will, which is less likely to work with horses than with humans. Nor is the horse likely to be enticed to drink on the promise of future carrots. Least likely is persuading the horse, for example, that it is in its best interest to drink as much water as it can now since it will be in the desert for several hours. Moreover, appealing to the horse's moral duty not to abuse its health would, of course, be absurd.

While horses like humans can be regulated by the blatant compulsive coercion of deterrence even a dog, to change the saying, knows the difference between being kicked and stepped on unlike humans, horses cannot be regulated by the subtle, impulsive coercion of enticement. Only humans can be persuaded to change their will or choice by the rational calculation that shows that accepting some pain now brings more pleasure later, and in that odd sense 'willingly' accept the coercion of the carrot for doing what another wishes contrary to one's presently preferred alternative courses of action. Such 'willingness' is the result of a form of coercion, I suggest, in the sense that one individual has subtly determined or limited the courses of conduct available to others.

10. ''Person' in Kant's wording is his practical (moral) imperative. Whle the notion of person becomes related to the one of individual human being as early as the thirteenth century (radically detaching itself from the Latin persona), Kant's principle that persons are not to be treated [merely or only] as 'means' but equally as 'ends in themselves' renders better than any other, I submit, the respect for 
To put the same point in specifics, government regulates individual behaviour coercively either by punishing to deter undesirable behaviour or by rewarding to entice desirable behaviour. The coercion which is familiar and obvious, because it is blatant, is, of course, the coercion government generates by threats of punishment to deter crime, regulatory offenses and disobedience to judicial orders. Charter rights clearly apply to restrict such blatant, compulsive coercion. Its legal rights (ss. 7-14) speak directly to punishment and other deprivations of life, liberty and security of the person. Such rights are designed to guarantee at a minimum that innocent individuals are not punished at all and that guilty individuals are only punished proportionately. The other Charter rights, which guarantee fundamental freedoms (s. 2), voting (ss. 3-5), fundamental justice generally (s. 7) and legal equality (s. 15(1)), are most obviously violated when government infringes them blatantly by compulsion. The question, however, is whether Charter rights in principle are restricted to interferences threatened by blatant coercion or instead extend to enticement regulation.

When government regulates by enticement, the coercive effect is not obvious, but subtle. It is the impulsive force found in licensing, contracting and subsidizing with or without conditions. Regulation may, of course, also take noncoercive, inspirational forms such as appeals in wartime to patriotism and in peacetime to more diffuse common values which if purely facilitative do not trigger the possibility of rights protection. In contrast, in licensing, contracting, conditioned subsidizing and unconditioned subsidizing, I argue, there is the possibility of subtle, impulsive coercion in the forms of clever dealing, unconscionable bargains, deceptive expectations and covert punishment.

First, in regulation by licensing the impulsive, subtle coercion comes about cleverly. It begins with a general prohibition on socially useful activity which in the main is lawful, but which at times may become unlawful. It does not become unlawful by committing distinct crimes such as murder, theft and fraud. It becomes unlawful when, for example, professionals like medical doctors and lawyers, whose competence and honesty the public must trust, lack such qualifications. Other activities also can pose danger to the public interest when they become unsafe, create nuisances or monopolize the market, such as in food and drug products, land development, environmental pollution, transportation and television, to mention a few. The general prohibition is initially arbitrary because the

the individual that Western civilization has come to cherish." Sartori, The Theory of Democracy Revisited: Part II: The Classical Issues (Chatham, New Jersey: Chatham House Publishers, 1987) at 294. The conceptual mistake of omitting "only" or "mere" is, unhappily, often made. See I. Kant, The Metaphysics of Morals trans. M. Gregor (Cambridge: Cambridge University Press, 1991) at 62: "Do not make yourself a mere means for others but be at the same time an end for them." For Kant, this is a juridical duty which comes, from the Right (Recht) of humanity in our own person to which every person owes respect.

11. National Bank of Canada v. R.C.U., [1984] 1 S.C.R. 269 at 295 illustrates vividly the principle in Big $M$ Drug Mart, supra note 9 that governmental intrusion must always respect the person by not treating people as means only in terms of thought control. In the case, the Canada Labour Relations Board ordered, as a remedy for deunionizing a bank by merger, the bank president to sign a letter written by the Board to express sympathy for union objectives and not to reveal the fact that the letter's contents were not his own thoughts leaving the impression that the Board's thoughts were his thoughts. Such Board action was characterized by the Court as totalitarian. 
activities proscribed are, as mentioned, mainly lawful and usually productive and valuable socially. Unless individual choice is to be despotically governed, everyone has the natural liberty to engage in such activities as of right until it can be shown that they have interfered with the like liberty of others.

This initial arbitrariness of the general prohibition, punishing lawful and unlawful activity as if they were the same, is justified only because the two sorts of activities cannot be identified in advance by outlawing, i.e., refusing to license, only individuals who will act unlawfully. This justification means that a second step must be taken in the sense that individuals who can satisfy the eligibility conditions, mainly by showing their competence and honesty, have a right in principle to a license, for example, to become a lawyer, ${ }^{12}$ to practice medicine in a location of one's choice, ${ }^{13}$ to sell oleomargarine ${ }^{14}$ and even to sell liquor. ${ }^{15}$ The license or other permission can be denied to applicants only when it is shown that granting a license in their case would endanger the public's interest, especially in safe, reliable services. If government were permanently to outlaw a lawful activity, for example, producing oleomargarine, which could not be shown as endangering health or misleading consumers, then it would appear that individuals would have the right under s. 7 to engage in the activity and no reasonable limitation on that right could be found under $s$. 1 . The clever coercion of producing a governmental benefit by generally prohibiting lawful activity and then using that as leverage for favouring certain special interests would appear in principle to attract $\mathrm{s} .7$ protection. ${ }^{16}$ Clever dealing overreaches its permissible limit when applicants who qualify for the license are refused it on irrelevant grounds as determined by the $s .1$ tests of legitimate objectives and proportional means. ${ }^{17}$ In such cases, the subtle, indirect coercion, because it arguably violates $\mathbf{s .} 7$ liberty, ought to be cancelled and the cleverly created governmental benefit, which is often valuable property, conferred. ${ }^{18}$

Secondly, in regulation by contracting the impulsive, subtle coercion arises when the contracting is unconscionable. Governmental contracting ranges over a wide variety of

Andrews v. Law Society of B.C., [1989] I S.C.R. 143 [hereinafter Andrews cited to S.C.R.]. Wilson v. Medical Services Com. of B.C. (1989), 53 D.L.R. 171.

See, e.g., Ref. Re s. 5(a) of the Dairy Industry Act, [1949] S.C.R. 1. Can. Federation of Agriculture v. A.G. Que. (Margarine Reference), [1951] A.C. 179.

See, e.g., Roncarelli v. Duplessis, [1959] S.C.R. 121.

In general terms, the s. 7 argument for reaching this result interprets the liberty of the person everyone has as a right as the liberty fit for a 'person.' Supra note 10. At a minimum, arguably, this means that government cannot, on the one hand, cleverly take away the liberty right to engage in lawful activity in order to prevent in advance unlawful activity and then, on the other hand, arbitrarily refuse individuals permission to engage in the lawful activity. In other words, government cannot for irrelevant reasons deny individuals lawful benefits they naturally have in the absence of licensing. It is difficult to imagine what a free and democratic society, as presupposed by $\mathbf{s .} 1$, means if it does not mean at least this.

17. See, for the s. 1 approach, R. v. Oakes, [1986] I S.C.R. 103.

It should be noted that conferring benefits through licensing regulation is not redistribution through taxation. It creates the benefit by the general prohibition against the activity. The benefit received by licensees, however, can have redistributive effect to their advantage when licensing is used not to protect the public but to lessen competition. Such uses of licensing regulation would appear inherently arbitrary. 
activities, but in all cases the government, which is treated as if it were a private person with the same rights and duties in exchanging its (public) property, has bargaining advantages which few private persons, even large corporations have. It does not have to contract in order to make a profitable deal and thus can entice people to agree by offering overly generous terms. Government also has a monopoly over certain employment opportunities, such as judges, police officers, planners, social workers and public administrators, which some people find irresistible.

While it is true that no one is forced in the blatant sense to be a judge, police officer or other government employee, it is also true that this truism assumes an equality of bargaining power which is simply false in principle when government is the other party. Judges, for example, may be required to surrender as the condition for their employment benefit their Charter right to engage in partisan politics and even their Charter right to vote. We may assume that they have been induced to do so because they value such a position so highly that they do not freely surrender their Charter rights. Such unconscionable coercion, like clever coercion, arguably attracts $\mathrm{s} .7$ protection, and should also be cancelled when the enticed waiver of one's fundamental rights or freedoms under the Charter could not be demonstrably justified as a reasonable limitation under s. 1. It may be, for example, that there is justification for denying judges and certain other government employees the right to engage in politics in order to keep political partisanship out of the administration of justice. But it would seem that there is no justification for denying government employees the right to vote, not even judges.

Thirdly, in regulation by conditioned subsidizing the impulsive, subtle coercion takes the form of deceptively enticing potential recipients to accept the bad with the good. It is the condition on the financial or other material benefit government proffers which serves regulatory policies ranging again across a wide variety of activities. These policies are implemented by inducing individuals to invest in government projects in reliance on the continuance of the conditioned benefit. The benefit itself can, of course, be delivered by risky loans or tax exemptions as well as by cash grants. But, however delivered, the benefit must be attractive enough to induce acceptance of the onerous condition. The success of such a strategy depends directly on the extent to which recipients are induced to believe that the benefits will not cease.

Regulation by the enticement of financial support is especially deceptive when the benefit is delivered by tax exemption. For example, private enterprise may be enticed by less taxes to build railroads which market calculations otherwise make unprofitable. To induce acceptance, the expectation has to be fostered that the tax exemption is permanent. But it is an essential rule, not widely recognized, that a legislature cannot fetter its future authority to legislate. Thus, government officials, perhaps sincerely, can persuade the legislature to provide the tax exemption to induce private investment to build unprofitable but publicly-needed facilities like railroads, and then later the legislature could repeal the tax exemption. The alternatives left for the owner are to operate at a loss, sell the assets below investment costs or go into bankruptcy. Presumably, the forced sale price would enable a successor to operate at a profit, unless the successor was also influenced by the 
deceptive expectations. ${ }^{19}$ The regulatory policy of promoting railroad service in an unprofitable market can thus succeed, but only because of coercion by deceptive expectations.

It is at least arguable in such cases that $\mathrm{s} .7$ would require a hearing before the tax exemption is repealed so that the legislature is judicially informed publicly of the impact the withdrawal of the benefit would have on recipients who were enticed to invest or otherwise rely by the expectation of the continuance of the benefit. It may even be arguable that included as a principle of fundamental justice is fair treatment to undo the deceptive expectation of a continuing tax exemption. That could be done by requiring government to provide a reasonable rate of return on the induced investment as if the investor were a public utility or by some other remedy under s. 24(1).

When regulation by subsidizing is unconditioned, it would appear that not even impulsive, subtle coercion would be implicated. Unlike conditioned subsidizing, the regulatory effect in changing behaviour does not come about by coercing choice in the sense of inducing investments or other commitments one would not otherwise make. Instead, existing choices of individuals happen to match governmental policy and the subsidizing is intended to reinforce such activity by removing financial obstacles or intensifying the commitment. Thus, it may be governmental policy to increase population by births, to further a more educated people, to guarantee adequate medical services, to save the home or family farm from mortgage foreclosures, to achieve energy self-sufficiency, to create employment opportunities, to promote research and development of business opportunities and the like. Such regulation seems purely facilitative. When such benefits cease, recipients are worse off than they would be had the benefits continued, but because the benefits were not conditioned, they are not worse off than they would be had they not accepted the benefits in the first place.

But unconditioned subsidizing, even though it does not directly induce commitments, may not always be purely facilitative. There can still be coercion by deceptive expectations. In providing unconditioned monthly family allowances, for example, recipients may as a result, as government intends, have more children than otherwise. Such recipients, to be sure, are not compelled by blatant coercion to have more children. But family allowances may not make it simply less onerous to have the same number of children a family would have were there no family allowances. They instead may make more children financially attractive, which is the regulatory purpose. In that case, the recipients are coercively impelled in subtle fashion to choose differently, and not simply facilitated to do what they would have chosen independently to do.

But again a legislature in making continuing subsidies cannot be fettered in its future discretion. If family allowances bring about the desired increase in population, then the public interest requires their termination. Here again, s. 7 would arguably require a public

See supra notes 3 and 5. In Esquimalt, the facts suggest that deceptive expectations may have been at the bottom of the controversy, but the conventional theory of characterizing benefits made relevant only the argument of a completed contract by statute, presumably done in a fashion which would not fetter the legislative power for the future. 
hearing to measure the impact on the recipients in terms of their induced reliance on continuance of the benefit. Government enticed that reliance and could reasonably foresee its results. It had the opportunity at the time to have given public notice that the monthly family allowances could be reduced or terminated at any time. Not giving that notice in fact creates the impulsive, subtle coercion on the choice of recipients to have more children than otherwise. Government could avoid that liability either by giving adequate notice to avoid the deceptive expectations or by providing family allowances, as in Quebec, as a one-time grant which would clearly indicate that the benefit is not to continue. ${ }^{20}$ Absent such notice or its equivalent, facilitative regulation, when it succeeds in altering conduct by inducing the choice to forgo alternatives, such as not having more children, would not be purely facilitative but significantly coercive.

Fourthly, in all four forms of enticement regulation, whether by licensing, contracting, conditioned subsidizing or unconditioned subsidizing, government is in the position to punish covertly. If it punishes overtly, that is, if officials openly disclose that the reason for revoking a license or repealing a tax exemption or ceasing to subsidize is to make examples of certain individuals to deter others from behaviour offensive to government, then such official malice is actionable not only for nullifying the decision but also for damages. ${ }^{21}$ The difficulty arises when officials, in refusing or terminating benefits, do not openly disclose their malice. By the conventional theory, when the benefits are mere privileges to government's largesse and not prior rights to licenses or contracted services, then they may be refused arbitrarily in the sense that no reasons at all need be given. Financial benefits are sufficiently different that they may be viewed as privileges and not as rights at common law. They are benefits which result not from private activity but from governmental assistance.

But despite this, it would seem that coercion by covert punishment, simply because it is coercion on the right to choose, would for that reason alone attract s. 7's fundamental justice protection. Or, in the alternative, for a different reason, it would arguably attract the nondiscrimination protection of s. 15's equality rights. It would seem that if benefits, even when unconditioned, are refused or terminated and if the individuals singled out for adverse treatment are situated similarly to others who receive the benefits, except for the motive to punish, such discrimination would seem sufficient to put government to the $s$. 1 tests.

Part of the conventional theory is that covert punishment is not in principle wrong. If government can punish directly the behaviour it punishes indirectly, whether it does so overtly or covertly, then it may do so. The reason seemingly goes back to the rule that the greater power to punish directly includes the lesser power to punish indirectly, especially when the indirect punishment is milder and less stigmatizing. Of course, on this argument, the conventional theory itself has to accept that it is wrong in a federal system for one level of government to exercise a power it does not have by punishing behaviour indirectly when it cannot punish it directly. But even when government has the power to for the benefit of raising children and may encourage irresponsible parenthood. 
punish certain behaviour directly, arguably for at least three reasons, it does not necessarily follow as a matter of fundamental justice that it is wholly free to punish the behaviour indirectly.

First, the punishment may be overreaching in that financial benefit is refused or terminated as to all activities of applicants or recipients when only part of the activities are deemed undesirable by government. Or, second, even if it is not overreaching, the indirect, covert punishment may wrongfully evade the Charter's procedural protections designed generally to guard against punishing the innocent or punishing the guilty disproportionately. Third and more importantly, even the power to punish blatantly and directly must, if law and not despotism is to rule, observe the minimal guarantee that even those guilty of committing proscribed acts not be punished when government has denied them the "liberty to omit." ${ }^{22}$

\section{PRACTICAL PROBLEMS OF ENTICEMENT REGULATION}

Prior to the enactment of the Charter and Constitution Act, $1982,{ }^{23}$ the conventional theory was authoritative by default. Except for certain anomalies like the group rights in education protected by s. 93, Constitution Act, 1867, legislative authority was then in principle unlimited in the sense that the two levels of government together had all of it. The judiciary had authority only to declare which level of government constitutionally had disputed power.

This fundamental constitutional rule of pre-Charter times is usefully illustrated in Harrison v. Carswell. ${ }^{24}$ Over a strong dissent by Laskin, C.J.C., the Supreme Court, in an opinion by Dickson, J. (as he then was), upheld the validity of the Manitoba Petty Trespass Act. The Act empowered the owner of a shopping mall to prohibit by the private use of the criminal law trespasses on its 'public premises.' The trespassing was peaceful picketing in a lawful strike. The sort of balancing of competing rights which the Charter could be interpreted as authorizing in $\mathbf{s .} 1$ was flatly rejected as outside the limits of the judicial function under the conventional theory. The legislature would have been free to permit such picketing in shopping malls, but it had not done so. That such picketing, if peaceful on public premises whether or not in connection with a lawful strike, would arguably have had Charter protection as expressive freedom, simply could not plausibly fit into a schema of governmental power which makes the only test of invalidity encroachments on the federal division of powers.

22. T. Hobbes, Leviathan, ed. by C.B. Mcpherson, (Harmondsworth, England: Penguin Books, 1968) at 262-63: "Feare and Liberty are consistent; as when a man....sometimes pays his debt, only for feare of Imprisonment, which because no body hindered him from detaining, was the action of a man at liberty. And generally all actions which men doe in Commonwealths, for feare of the law, or actions, which doers had the liberty to omit."

23. Being Schedule B to the Canada Act 1982 (U.K) 1982, c. 11 [hereinafter Constitution Act, /982].

24. Harrison v. Carswell (1976), 62 D.L.R.(3d) 68 
The same foundation by default for the conventional theory is also exemplified by Roncarelli v. Duplessis, ${ }^{25}$ but with a different result. Roncarelli had his restaurant's liquor permit cancelled on orders of the Attorney General (who was also Quebec's prime minister) who believed that he was engaged in seditious conspiracy. The permit could have been cancelled at the discretion of the one-person Liquor Commission, but in exercising its cancellation power, the Commission had not exercised its discretion independently acting instead by dictation from the Attorney General. Roncarelli, who had sold his restaurant for a loss, sued not for the permit but for damages which he was awarded on the grounds that the Attorney General acted with malice outside his statutory authority.

Seditious libel is a crime which the Federal and not the provincial governments has the power to punish. It may have been the case that Roncarelli could have been convicted of seditious libel under the Canadian Criminal Code or more likely for something like conspiracy in publicly distributing hate propaganda against Catholics. Thus, the central question in the case was not whether Roncarelli had fundamental justice rights against legislative authority. It was only whether officials authorized by statute to exercise certain powers, when they use their office to harm individuals, act in good faith. Implicit in the Roncarelli decision is the conventional theory that the level of government with the criminal law power, which in Canada is the Federal government, could have authorized the cancellation of the liquor permit for suspected seditious conspiracy or the like. Having that power to punish Roncarelli directly, the Federal government, as the conventional theory further holds, could have punished him indirectly.

That the Charter has now radically changed this conventional schema of governmental power should by now be a familiar story. It can no longer be true that simply because government has the greater power it can exercise a lesser power, that what it can punish directly it can punish indirectly, that benefits it creates are merely privileges and that individuals have no right to Charter rights when they choose to waive such rights to get governmental benefits others cannot get. Before the Charter, to take the most important example of the schematic change, it was, on the conventional theory, clearly within Federal powers to enact as valid law the Lord's Day Act. One or the other level of government had to have the power to make it a crime to do business on the Sabbath, and as long as the behaviour to be prohibited and punished is clearly described in advance to avoid denying the 'liberty to omit,' the Act had to be valid.

The Supreme Court unanimously in R. v. Big M Drug Mart Ltd. ${ }^{26}$ held the Lord's Day Act invalid as infringing s. 2(a) freedom of conscience and religion. While the Act was within the criminal law power of the Federal government, it had the religious purpose of coercing individual choice to follow the Christian belief in observing Sunday as the Sabbath. Such coercion blatantly compelled businesses to close on Sundays and subtly constrained buyers from buying. While the Act facilitated the wishes of Christian 
adherents, nonetheless it removed the voluntary nature of their choice to observe their Sabbath. As Dickson, C.J.C., stated:

\begin{abstract}
Coercion includes not only such blatant forms of compulsion as direct commands to act or refrain from acting on pain of sanction, coercion includes indirect forms of control which determine or limit altemative courses of conduct available to others....Freedom means that, subject to such limitations as are necessary to protect public safety, order, health, or morals or the fundamental rights and freedoms of others, no one is forced to act in a way contrary to his beliefs or his conscience."27
\end{abstract}

This freedom from indirect or subtle as well as direct, blatant coercion, for Dickson, is founded "in respect for the inherent dignity and the inviolable rights of the human person. ${ }^{28}$

The same concept of freedom, which radically alters the conventional schema, underlies the Supreme Court's unanimous decision in Re B.C. Motor Vehicle Act. ${ }^{29}$ The province, in order to discourage dangerous driving, threatened drivers whose licenses were suspended or revoked with an automatic seven days in prison if they drove after suspension or revocation. This liability was absolute in the sense that they were to be given the prison sentence even if they had no fair opportunity to know of the invalidation of their licenses. In other words, they had no 'liberty to omit' the proscribed act nor the opportunity to prove that they acted without mens rea. While absolute liability per se does not violate principles of fundamental justice, such liability has that effect when it has the potential of depriving individuals of their life, liberty or security of the person. For this to happen, it is not necessary that imprisonment be mandatory. It is sufficient that such blatant coercion threaten the deprivation of liberty. ${ }^{30}$ Driving on public roads is, of course, a privilege in the sense that to have the right to a license one must show the competence to drive safely. The public roads are a benefit created by government, not by individuals without governmental assistance. No one's liberty right is taken away when drivers lose their license for dangerous driving. But the liberty right is infringed when one is blatantly coerced by the threat of punishment not to drive with an invalidated license; and when that threat applies to drivers who can have no reasonable opportunity to know that one's license has been invalidated, it is coercion contrary to the principle of fundamental justice that before one is punished for doing proscribed acts one must have the liberty to omit them.

In Roncarelli, it may be recalled, the statute was interpreted as not including within administrative discretion the power to cancel a license for acts irrelevant to the regulatory purpose. One reason for such a holding is that when licenses are cancelled for conduct irrelevant to the licensing purpose there is no chance that at the time of acting the act could be known to be prohibited. But, by the conventional theory, had the statute clearly given such a power, despite its conflict with principles of fundamental justice, licenses could be legally revoked retroactively for committing acts which at the time were not

lbid. at 336.

[1985] 2 S.C.R. 486.

Ibid. at 515 . 
proscribed. Re B.C. Motor Vehicle Act implicitly recognizes only the legislative authority arbitrarily first to prohibit all lawful activity like driving on public roads, and then to permit only if there is a right to a license on a showing of competency to drive safely. Thus, in withdrawing the privilege of driving, legislative authority can no longer simply rely on the conventional theory that the greater power includes the lesser power. While it can initially prohibit everyone from driving, it may not condition that benefit as it sees fit. In particular, it may not condition driving licenses with the condition that one may be imprisoned for acts which one did not have the 'liberty to omit' even though such a measure is rationally connected to keeping the roads safe from careless drivers.

In Wilson, ${ }^{31}$ the liberty right in $\mathrm{s.} 7$ invalidated B. C. legislation which effectively restricted the right to practice medicine by qualified medical doctors. The legislation conditioned their right to locate their practice by requiring them to obtain a number for billing medicare. The numbers were assigned with a view to subtly coerce medical doctors to locate in rural areas as well as to control medical costs. A unanimous B.C. Court of Appeal held that such control over the lawful activity of qualified medical doctors, which was essentially a license on a license, impugned their dignity and sense of self-worth. The liberty to locate one's medical practice is a mobility right not limited to s. 6; it is also included in s. 7's right to liberty to practice a lawful vocation in a location of one's choosing.

The fact that medicare payments are a benefit created by government did not hinder the Court in finding that the licensing by billing numbers was manifestly unfair in terms of the adverse effect the subtle coercion had on applicants whose medical competence could not be questioned. The Court found in effect that in light of their investment in becoming qualified medical practitioners, subsequent interference with their choice of location suggested coercion by deceptive expectations. More to the point, government could cleverly coerce their choice of alternatives in locating their practice only if cost control could not be achieved in other ways, which was not true, and the locational distribution of medical services had the compelling importance which warrants the intrusion on their liberty of choice, which it did not have.

So far, case law arguably supports the thesis that Charter rights have significantly altered the conventional theory's schema that governmental power, except for its federal division, always validates itself. Under that schema, if the denial of liberty is cast in clear statutory language, even the 'liberty to omit' as protected in Re B.C. Motor Vehicle Act as a s. 7 liberty would have no guarantee even against blatant coercion. Wilson holds that the liberty to engage in lawful activity is protected by $\mathbf{s .} 7$ against subtle, impulsive as well as blatant, compulsive coercion. While dangerous driving is not a lawful activity, locating one's medical practice is such an activity and may be restricted only on a showing that the restriction is a necessary and appropriate means to a compelling public interest. Blatant coercion, of course, is ruled out directly, as Big $M$ shows, when it intrudes on fundamental freedoms such as conscience and religion. But subtle coercion to prohibit business on Sundays appears permitted by the Charter when the purpose of 
the prohibition and licensing is not sectarian but the secular one of a community day of rest. But even then the clever dealing must not go too far in violating religious liberty by indiscriminately refusing licenses, as it were, to those who observe the Sabbath on a different week day. ${ }^{32}$

Although Andrews ${ }^{33}$ relies on s. 15 to void the B.C. statute which required Canadian citizenship as a condition for admission to the practice of law, the case also stands for the protection of the liberty right to engage in lawful behaviour without restriction by reason of irrelevant purposes. In that case, applicants for admission to practice law, a benefit which exists without governmental assistance but which government confers by clever dealing, were qualified in terms of competence and honesty but lacked Canadian citizenship. Except for special positions, such as advising a government, such a condition was found irrelevant. The holding could have been grounded in $\mathbf{s .} 7$ liberty as a right against the deprivation of liberty to engage in lawful activity for irrelevant reasons. But it instead was argued and decided on the basis that the applicants were singled out of the class of competent lawyers for special, adverse treatment, and that special treatment as a noncitizen in such circumstances constituted treatment in terms of personal characteristics analogous to the invidious traits listed in s. 15(1). Refusing noncitizens the license to practice law in such circumstances denied them equal protection and equal benefit of the law. The effect, of course, was to cancel the subtle coercion of clever dealing which regulation by licensing makes possible. The alternative of becoming a lawyer without becoming a citizen was no longer foreclosed in principle to noncitizens.

So far, I suggest, the direction of Charter interpretation is away from the conventional schema - the schema that governmental power, once it is found not to encroach too much on the powers of the other level of government, validates - itself to a schema in which governmental power must find its validation also within the broad concept of the prior liberty of the person. This prior liberty is not simply the liberty right to engage in lawful activity as long as one does not act unlawfully. Nor is it only the 'liberty to omit' before one can be blatantly punished for unlawful acts. It is also the essential liberty of the 'person' as a rational moral being, ${ }^{34}$ the liberty not to be treated as a means only for the greater utility of the political majority, unless the public interest is so compelling an end in the circumstances that morally innocent persons may be denied priceless dignity.

There appears to be no Charter case yet on the constitutional validity of regulation by financial incentives in which the benefit offered as the means of enticement regulation is wholly created by government. ${ }^{35}$ Such cases, of course, are possible, and hypothesizing them shows, I argue, that in principle they cannot escape the liberty schema of govern-

R. v. Edwards Books \& Art Lid., [1986] 2 S.C.R. 713. In fact, the majority held that the coercion which would qualify as s. 32 action and thus trigger s. 2(a) of the Charter did not have to come from the government. In the absence of a Sunday closing law, Saturday observers would still be coerced by their religion to do business on one less day than nonobservers. The closing law only equalized the days of business between nonobservers and Sunday observers by coercing non-observers to close on Sundays.

33. Supra note 12.

3. Supra note 10.

35. At the date of writing the paper: August 1990. 
mental power. The obvious example concerns judges. Their traditional political independence protected by special constitutional provision is designed to protect them from the subtle coercion made possible by implicit threats to reduce their salary or to remove them from office. But at the same time they are denied Charter rights to vote and engage in political activities. The conventional theory's schema provides them with no plausible argument and in fact suggests that judges who 'voluntarily' accept the obligation not to engage in partisan politics and not to vote, if they complain, simply wish to have their cake and eat it, too.

The Charter's liberty schema, however, does, I suggest, provide judges with a plausible argument of principle. Anyone who must surrender their political rights as a condition of government employment arguably have their s. 2(b) freedom of expression, their s. 2(d) freedom of association, their s. 7 liberty and their s. 15 equality rights infringed. While government likely can sustain its $s$. 1 burden to justify infringing such rights on the ground that it is important in a free and democratic society to keep partisan politics out of the administration of justice, there is strong doubt that it could do so with respect to the $\mathbf{s}$. 3 right to vote. On the same principle that liberty is denied whenever coerced, blatantly or subtly, it would also appear that governmental employees not involved in the administration of justice could not be coerced to accept the condition of waiving their political rights, except as to holding political office as a second position.

The argument on this hypothesized case and others like it is not, it should be stressed, that the liberty schema always dictates a different result from the conventional power schema whenever regulatory enticement is coercive and not purely facilitative. It is rather that whatever the result, the Charter now makes the rules of the liberty schema the overriding game, as it were, and in that game, if played with integrity, ${ }^{36}$ it should be only a matter of time before the various modes of regulation by financial and other enticement incentives come under close judicial scrutiny. Not for this development to take place would require an incoherent view of s. 32: that the Charter is to apply to all matters of legislative authority except when that authority relies on subtle coercion by enticement instead of on blatant coercion by compulsion. ${ }^{37}$ The better argument, I suggest, has the Charter in principle not applying to legislative authority only when such authority regulates purely by facilitation.

The notion of integrity in interpreting the law as a matter of principle is, of course, controversial, but it seems the judicial method and approach most apt for the Charter in finding violations of rights. Conventionalism and pragmatism would appear to have relevancy, if at all. to the $\mathrm{s}$. I analysis. See generally, R.M. Dworkin, Law's Empire (Cambridge: Belknapp Press of Harvard University Press, 1986) especially at 189.

Professional Institute of the Public Service of Canada v. Commissioner of N.W.T. (1990), 72 D.L.R. (4th) 1 at 19: In holding that a government conferring the benelit of collective bargaining on its employees had no duty to grant such a right to the mere shell of a labour union, Sopinka, J. stated: "I do not wish, however, to be taken as sanctioning the view that where a government confers a benefit it is entitled to attach whatever conditions it pleases to the receipt of the benefit. Any such conditions must themselves pass constitutional muster. It seems obvious, for example, that a government could not grant collective bargaining rights on a basis that would contravene the equality rights guarantees contained in s. 15(1) of the Charter." 